Abstracta Iranica Abstracta Iranica

Revue bibliographique pour le domaine irano-aryen

Volume 29 | 2008

Comptes rendus des publications de 2006

\title{
Islam and Democracy in Iran. Eshkevari and the Quest for Freedom. London, I.B.Tauris, 2006, 198 p.
}

Azadeh Kian-Thiébaut

\section{OpenEdition}

1 Journals

Édition électronique

URL : http://journals.openedition.org/abstractairanica/32482

DOI : 10.4000/abstractairanica.32482

ISSN : 1961-960X

\section{Éditeur :}

CNRS (UMR 7528 Mondes iraniens et indiens), Éditions de l'IFRI

\section{Édition imprimée}

Date de publication : 15 mai 2008

ISSN : 0240-8910

\section{Référence électronique}

Azadeh Kian-Thiébaut, "Islam and Democracy in Iran. Eshkevari and the Quest for Freedom. London, I.B.Tauris, 2006, 198 p. », Abstracta Iranica [En ligne], Volume 29 | 2008, document 375, mis en ligne le 15 septembre 2008, consulté le 26 septembre 2020. URL : http://journals.openedition.org/ abstractairanica/32482 ; DOI : https://doi.org/10.4000/abstractairanica.32482

Ce document a été généré automatiquement le 26 septembre 2020.

Tous droits réservés 


\title{
Islam and Democracy in Iran. Eshkevari and the Quest for Freedom. London, I.B.Tauris, 2006, 198 p.
}

\author{
Azadeh Kian-Thiébaut
}

1 Au travers de la traduction d'une sélection d'ouvrages de Hasan Yousefi Eshkevari portant notamment sur l'islam et la démocratie, ce livre raconte en fait l'émergence et la montée du mouvement réformiste en Iran dans les années 1990. L'un des clercs les plus en vue de l'Iran post-révolutionnaire, Eshkevari, fut condamné à la peine capitale en 2000 pour apostasie suite à sa participation à la conférence de Berlin, avant de voir sa peine commuée en cinq années d'emprisonnement. Afin d'informer le public non spécialisé, le livre présente le contexte historique du débat islam-démocratie et des tensions existantes entre religiosité et laïcité d'une part, despotisme et démocratie, d'autre part. Le chapitre suivant présente la vie privée et publique de Eshkevari et son projet de marier la foi et la raison. Le lecteur est ensuite introduit à la philosophie politique de Eshkevari où sont développés sa perspective de gouvernement démocratique islamique et la compatibilité entre islam et démocratie. Il défend l'idée selon laquelle l'islam en tant que religion ne prescrit aucun système politique spécifique, que le politique est toujours laïc et que le règne du Prophète à Médine était en fait de nature laïque. Les chapitres suivants présentent un dialogue entre Eshkevari et Mohammad Quchani, un jeune intellectuel islamique. Les contributions de Eshkevari à la conférence de Berlin constituent des textes politiques qui plaident pour un islam démocratique. Quant aux droits des femmes en islam, Eshkevari rejette le port obligatoire du voile et défend les droits des femmes musulmanes. 
INDEX

Thèmes : 13.1. Iran

\section{AUTEURS}

AZADEH KIAN-THIÉBAUT

Université Paris VII / Mondes iranien et indien 